\title{
Prion (PrPC) expression in ovine uteroplacental tissues increases after estrogen treatment of ovariectomized ewes and during early pregnancy
}

\author{
Mary Lynn Johnson ${ }^{1,2}$, Anna T Grazul-Bilska ${ }^{1,2}$, Lawrence P Reynolds ${ }^{1,2}$ and Dale A Redmer ${ }^{1,2}$ \\ ${ }^{1}$ Department of Animal Sciences and ${ }^{2}$ Center for Nutrition and Pregnancy, North Dakota State University, \\ Fargo, North Dakota 58108, USA
}

Correspondence should be addressed to M L Johnson; Email: mary.lynn.johnson@ndsu.edu

\begin{abstract}
Scrapie in sheep is spread laterally by placental transmission of an infectious misfolded form (PrPSc) of a normal prion protein (PrPC) used as a template in PrPSc formation. We hypothesized that PrPC would be expressed in uterine and placental tissues and estradiol-17 $\beta$ $\left(E_{2}\right)$ would affect uterine PrPC expression. PrPC expression was evaluated in the uterus of long-term ovariectomized (OVX) ewes treated with an $\mathrm{E}_{2}$ implant for 2-24 $\mathrm{h}$ and in uteroplacental tissues from day 20 to day 30 of pregnancy. Expression of PrPC mRNA and PrPC protein increased in the uterus after $E_{2}$ treatment of OVX ewes. In the maternal placenta, expression of PrPC mRNA and PrPC protein were unchanged, but in the fetal membranes (FM) PrPC mRNA and PrPC protein expression increased from day 20 to day 28. In the nonpregnant uterus, PrPC protein was immunolocalized at apical borders of the surface epithelium, in outer smooth muscle layers of large blood vessels, and in scattered stromal cells of the deep intercaruncular areas of the uterus. In the maternal placenta, PrPC protein was immunolocalized in the cytoplasm of flattened luminal epithelial cells apposed to the FM, whereas in the FM PrPC protein was in trophoblast cells and was also in several tissues of the developing embryo during early pregnancy. These data linking estrogen stimulation to increases in PrPC expression in uteroplacental tissues suggest that PrPC has a specific function during the estrous cycle and early pregnancy. Future studies should determine whether or not estrogen influences PrPC expression in other tissues, such as the nervous system and brain.
\end{abstract}

Reproduction (2014) 148 1-10

\section{Introduction}

Scrapie is a fatal and incurable neurological disease in sheep and belongs to a family of prion diseases known as transmissible spongiform encephalopathies (TSEs). Other well-known members of the prion disease family include bovine spongiform encephalopathy (BSE), variant Creutzfeldt-Jakob disease (the disease associated with BSE transmission to humans), and chronic wasting disease of Cervidae (deer, elk, moose, and related species). Scrapie is believed to be transmitted laterally (from sheep to sheep) via ingestion of the infected placenta at lambing. However, the mechanisms of scrapie transmission are not fully understood nor are the cells responsible for transfer and conversion of the normal prion protein (PrPC) to the abnormal infectious protein (PrPSc) positively identified. Nevertheless, PrPC must be present as it acts as a template for the conversion to PrPSc (Brandner et al. 1996, Colby \& Prusiner 2011). PrPC has previously been found in numerous sheep reproductive tissues and shown to increase during pregnancy in caruncular (CAR) endometrium
(Tuo et al. 2001). PrPC has also been detected in sheep blood (Halliday et al. 2005).

The precise physiological role of PrPC is presently unknown. However, a few of the functions that have been proposed for PrPC include neuroprotection, protection against oxidative stress, promotion of cell signaling cascades, involvement in cell adhesion, a role in cancer processes involving either inhibition or promotion of apoptosis, and a role in progression of Alzheimer's disease (AD; reviewed in Nicholas et al. (2009) and Mehrpour \& Codogno (2010)). Additionally, Alfaidy et al. (2013) have reported that PrPC affects key angiogenic processes necessary for establishment of fetomaternal circulation and subsequent growth of the placenta through modulation of copper $(\mathrm{Cu})$ homeostasis in humans. Either overexpression or no expression of PrPC in genetically engineered mice was shown to cause intrauterine growth retardation (IUGR), which is a major complication of pregnancy (Alfaidy et al. 2013). Thus, it seems apparent that PrPC expression plays a role in early placental development, but quantification of PrPC 
expression during early pregnancy and determination of which cells express PrPC has not been reported.

Estradiol-17 $\beta\left(E_{2}\right)$ is a known modulator of the cyclic patterns of uterine growth and tissue remodeling that occurs during the estrous cycle (Reynolds \& Redmer 2001, Reynolds et al. 2002). The uterotropic effects of $E_{2}$ during early pregnancy promote increased blood flow to support embryonic development and placentation (Magness et al. 1998, Reynolds et al. 1998a,b, 2002, $2004,2010)$. Besides promoting blood flow, $E_{2}$ has profound effects on various factors that promote angiogenesis and affect uteroplacental cell proliferation, growth, and differentiation (Reynolds \& Redmer 1992, 1995, 2001, Johnson et al. 1997, 2006, Reynolds et al. 1998a,b, 2010). Similarly, based on the interaction of PrPC with proteins known to be active in cell signaling pathways, a role for PrPC in promoting cell survival, differentiation, and prevention of apoptosis has been proposed (Nicholas et al. 2009, Mehrpour \& Codogno 2010, Rigter et al. 2010). However, whether or not $E_{2}$ might promote increased expression of PrPC during growth of uterine tissues has not been evaluated.

We have developed a well-tested ovariectomized $(\mathrm{OVX})$ ewe model for examining the effects of $E_{2}$ on growth and vascularization of endometrial tissues (Johnson et al. 1997, 2006, Reynolds et al. 1998a,b), and we have established another model for studying placental development during early pregnancy (Reynolds \& Redmer 1992, 1995, Grazul-Bilska et al. 2010, 2011). These models are used in this study to examine whether or not PrPC expression is influenced by $E_{2}$ and is developmentally regulated during early pregnancy. Our hypothesis was that expression of PrPC mRNA and/or PrPC protein would increase in a cell-specific manner in the uterus after $E_{2}$ treatment in long-term OVX ewes and would increase in uteroplacental tissues and the developing embryo from day 20 to day 30 after mating during early pregnancy in sheep. Our objectives were: i) to quantify the effects of $\mathrm{E}_{2}$ treatment on uterine $\operatorname{PrPC}$ mRNA and PrPC protein expression in OVX ewes, ii) to quantify levels of uteroplacental $\operatorname{PrPC}$ mRNA and PrPC protein expression from day 20 to day 30 of early pregnancy, and iii) to localize PrPC protein in specific endometrial cells after $E_{2}$ treatment and in placental and embryonic tissues during early pregnancy.

\section{Materials and methods}

\section{Animals and treatments}

For both experiments, all animal use and care procedures were approved by the Institutional Animal Care and Use Committee at NDSU.

\section{Experiment 1}

To examine the effects of $\mathrm{E}_{2}$ treatment on PrPC mRNA and PrPC protein expression, we used an OVX ewe model that we have previously validated and described in several studies (Johnson et al. 1997, 2006, Reynolds et al. 1998a,b). Briefly, on days 10-12 after estrus, ewes $(n=32)$ of mixed breed were OVX and allowed to recover for at least 30 days before steroid treatment was initiated. Two silicone elastomer implants containing $100 \mathrm{mg}$ of $\mathrm{E}_{2}$ were inserted subcutaneously into each ewe, and the uterus was collected at $0 \mathrm{~h}$ (controls), or at 2, 4, 8, 16, or $24 \mathrm{~h}$ after receiving the $\mathrm{E}_{2}$ implant $(n=4-6$ per time point; Johnson et al. 1997, Reynolds et al. 1998a,b). After weighing the intact uterus, CAR and intercaruncular (ICAR) tissues were dissected from the endometrium; one portion was snap-frozen and stored at $-70{ }^{\circ} \mathrm{C}$ for isolation of mRNA and protein, and the second portion was fixed in formalin for immunolocalization of PrPC protein. In the sheep endometrium, the CAR tissue contains numerous blood vessels, but no glands, whereas ICAR tissue contains secretory glands and blood vessels. Therefore, these two areas of the endometrium are not only morphologically different, but also functionally different tissues, which is why we collected them separately.

\section{Experiment 2}

The animal model for this experiment has been described in detail by Grazul-Bilska et al. (2010, 2011). Briefly, mature, nonpregnant (NP), western range-type ewes $(n=38)$ of mixed breed (predominantly Targhee $\times$ Rambouillet) were checked twice daily for behavioral estrus using vasectomized rams and were bred at estrus (day $0=$ day of estrus) by intact rams. Maternal placenta (CAR), and fetal membranes (FM) or chorioallantois of the fetal placenta, and developing embryos ( $n=1-3$ /ewe) were collected from ewes on days 20, 22, 24, 26, 28 , and 30 of pregnancy $(n=5 /$ day), and CAR tissue was collected from NP ewes $(n=5)$ on day 10 of the estrous cycle (controls). Similar to Experiment 1, a portion of CAR tissue, and FM were snap-frozen and stored at $-70{ }^{\circ} \mathrm{C}$ for isolation of mRNA and protein, and developing embryos ( $n=1 /$ ewe) as well as a cross section of uterus containing placental tissue were fixed in formalin for immunolocalization of PrPC protein.

In both experiments, quantitative real-time RT-PCR (qRTPCR) was used for analysis of PrPC mRNA expression, immunohistochemistry was used for localization of PrPC protein to specific cell/tissue compartments, and western analysis was used for quantification of PrPC protein expression.

\section{Quantitative real-time RT-PCR analysis of PrPC mRNA expression}

The procedures for determining the expression of mRNA for $\operatorname{PrPC}$ in ovine $\mathrm{E}_{2}$-treated endometrium, uteroplacenta, and embryo by qRT-PCR were reported previously (Johnson et al. 2006, Grazul-Bilska et al. 2010). Briefly, snap-frozen tissues were homogenized in Tri-Reagent (Molecular Research, Inc., Cincinnati, OH, USA) according to the manufacturer's specifications. The quality and quantity of total RNA were determined by capillary electrophoresis using the Agilent 2100 Bioanalyzer (Agilent Technologies, Wilmington, DE, USA). Quantitative real-time RT-PCR reagents, TaqMan probes, and primers were purchased from and used as recommended by Applied Biosystems. For each sample, 30 ng of total RNA were 
reverse transcribed with random hexamers in triplicate $20 \mu \mathrm{l}$ reactions. PrPC sequence-specific TaqMan probe and primer sets were designed from $100 \%$ homologous regions in the $5^{\prime}$ end of the sheep prion gene (forward, $5^{\prime}$-TTTGTGGCCATGTGGAGTGA-3'; reverse, 5'TCCATCCTCCGCCAGGTT-3'; and FAM-labeled MGB probe, 5'-CCTCTGCAAGAAGCGA-3; accession numbers JX187517-J187539) using the Primer Express Software from Applied Biosystems (Johnson et al. 2006, Evoniuk et al. 2007). The sequences were validated using NCBI BLAST separately on the primers, probe, and entire amplicon.

The ABI PRISM 7000 was used for detection of sequences amplified in a $12.5-\mu \mathrm{l}$ reaction volume at $60^{\circ} \mathrm{C}$ for 40 cycles (Applied Biosystems) in triplicate wells. Quantification was determined from a relative standard curve of dilutions of the cDNA generated from tcRNA pooled from placentomes collected on day 130 of pregnancy. To control for variations in the amount of RNA used, individual samples were simultaneously analyzed in a multiplex reaction for concentrations of 18S RNA using the 18S PDAR kit from Applied Biosystems, as we have described previously (Grazul-Bilska et al. 2010).

\section{Western analysis}

For CAR and ICAR tissues, and FM, protein fractions from TriReagent extractions were used for western analysis following the manufacturer's revised protocol. Briefly, proteins were precipitated with three volumes of $100 \%$ isopropanol, and the pellet was washed three times with $0.3 \mathrm{M}$ guanidine hydrochloride in $95 \%$ ethanol $+2.5 \%$ glycerol $(\mathrm{V}: \mathrm{V})$ with a final wash with ethanol $+2.5 \%$ glycerol. After briefly drying the pellet, it was solubilized in $1 \%$ SDS and quantified with the Bradford reagent (Wenrich \& Trumbo 2012). To quantify PrPC expression by western analysis, $30 \mu \mathrm{g}$ of PrPC protein were electrophoresed in a $12 \%$ SDS-PAGE gel, and transferred onto an Immobilon-P membrane (EMD Millipore Corporation, Billerica, MA, USA) that had been wet in methanol and rinsed three times with $\mathrm{dH}_{2} \mathrm{O}$. The membrane was blocked in $5 \%$ skim milk with PBS containing $0.1 \%$ Tween 20 (PBST) for $4 \mathrm{~h}$ at room temperature and then incubated overnight at $4{ }^{\circ} \mathrm{C}$ with primary MAB (SAF-32; Cayman Chemical Co, Ann Arbor, MI, USA) at a concentration of $1 \mu \mathrm{g} / \mathrm{ml}$ in $5 \%$ skim milk containing $0.1 \%$ PBST. After rinsing the membrane three times for $15 \mathrm{~min}$ with PBST, secondary goat anti-mouse antibody (Pierce, Rockford, IL, USA) was added to $5 \%$ milk containing $0.1 \%$ PBST and the membrane was incubated for $1 \mathrm{~h}$ at room temperature. The membrane was washed three times for 15 min each with PBST, and PrPC protein was quantified using Pierce ECL Western blotting substrate (Thermo Fisher Scientific, Inc., Rockford, IL, USA) according to the manufacturer's instruction and densitometry using the AlphaEase FC Image and Analysis software and the FluroChem FC2 Imaging System from Alpha Innotech (ProteinSimple, Santa Clara, CA, USA).

\section{Immunolocalization of PrPC protein}

PrPC was detected in formalin-fixed $4-\mu \mathrm{m}$ tissue sections (Experiment 1, $n=4-6$ slides/h; Experiment 2, $n=5$ slides/day; each slide was from a different ewe) as described previously
(Evoniuk et al. 2007). Two 5-min incubations in citrate buffer $(10 \mathrm{mM}, \mathrm{pH} 6.0$ at $90 \%)$ at $100{ }^{\circ} \mathrm{C}$ were used for antigen retrieval with a 5 -min cooling period between incubations, and a final 30-min cooling period before rinsing with $\mathrm{dH}_{2} \mathrm{O}$. Endogenous peroxidase was blocked for 5 min with $3 \% \mathrm{H}_{2} \mathrm{O}_{2}$ and neutralized for $5 \mathrm{~min}$ with water and $10 \mathrm{~min}$ with PBS containing $0.3 \%$ Triton X (EM Science, Darmstadt, Germany). Sections were then transferred to an automated staining system (DAKO Autostainer Universal Staining System, Cupertino, CA, USA) for primary anti-PrPC MAB (SAF 32 at 1:150; Cayman Chemical Company) staining. Primary antibody was detected with horse anti-mouse secondary antibody conjugated with HRP complex reagents (ImmPress kit Vector Laboratories, Burlingame, CA, USA) and Silver Grey (SG, Vector Laboratories) as the substrate. Sections were then counterstained with nuclear fast red (Sigma Chemical Co.). Control sections were processed identically but with mouse IgG in place of the primary antibody. Images were taken using an Eclipse E600 Nikon microscope and a digital camera (Nikon Instruments, Inc., Melville, NY, USA) or a Zeiss Imager M2 epifluorescence microscope equipped with Zeiss piezo automated stage and AxioCam HRm camera (Carl Zeiss International, Jena, Germany).

\section{Statistical analysis}

Data were analyzed using the general linear models procedure of the Statistical Analysis System (SAS 2008), with time after $E_{2}$ or day of pregnancy as the main effect and the interaction of time (day) and tissue included in the model. Data for qRT-PCR detection of PrPC mRNA and western analysis of PrPC protein in Experiment 1 were converted to fold increase above controls $(0 \mathrm{~h})$ which were set at 1, whereas in Experiment 2 the raw data obtained directly from qRT-PCR or densitometry analyses were statistically analyzed. Differences between specific means were determined using post-hoc analysis by the least significance difference test (Kirk 1982).

\section{Results \\ Experiment 1}

Expression of $\operatorname{PrPC}$ mRNA in CAR tissue increased $(P<0.01)$ by $\sim 1.5$-fold after $8 \mathrm{~h}$ of $\mathrm{E}_{2}$ treatment and then decreased $(P<0.02)$ to half that of controls at $24 \mathrm{~h}$ after $\mathrm{E}_{2}$ (Fig. 1). However, in ICAR tissue, PrPC mRNA expression was statistically unchanged from 2 to $24 \mathrm{~h}$ after $E_{2}$ treatment (Fig. 1) even though the pattern of expression was similar to CAR tissue.

PrPC protein, with a size estimated between 30 and $40 \mathrm{kDa}$ was detected by western immunoblot analysis in both CAR and ICAR tissues (shown at top of Fig. 2). PrPC protein expression increased $(P<0.02)$ by approximately two- to threefold in both CAR and ICAR tissues, at 2-24 $\mathrm{h}$ after $\mathrm{E}_{2}$ treatment (Fig. 2).

As the patterns of mRNA and protein expression were similar in CAR and ICAR tissues, there was no significant tissue by time interaction for either of them $(P>0.1)$. 


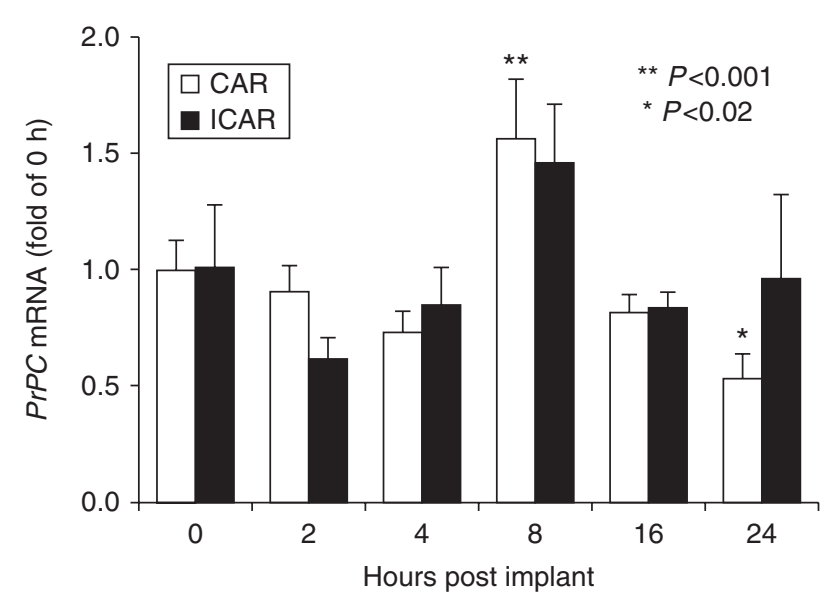

Figure 1 Expression of $\operatorname{PrPC}$ mRNA in CAR and ICAR tissues of $E_{2}$-treated OVX ewes. Data were converted to fold increase over $0 \mathrm{~h}$ (controls), which were set at 1.0. ${ }^{*} P<0.02 ; * * P<0.001$; means \pm S.E.M. are from qRT-PCR. PrPC mRNA increased by 1.5 -fold at $8 \mathrm{~h}$ after $\mathrm{E}_{2}$ treatment and decreased to half that at $0 \mathrm{~h}$ by $24 \mathrm{~h}$ after $\mathrm{E}_{2}$ treatment in CAR tissue, but $\operatorname{Pr} P C$ mRNA expression was unchanged in ICAR tissue.

Immunolocalization of PrPC protein in the endometrium of $E_{2}$-treated OVX ewes revealed that PrPC was predominantly found in arterioles and venules of both CAR and ICAR tissues of all samples (Fig. 3). PrPC was not found in uterine glands. The intense staining for PrPC protein seen in blood vessels was present in cells that appeared to be vascular smooth muscle and adventitial cells, but was not found in the endothelial cell layer of these blood vessels. At 16-24 h after $E_{2}$ treatment, PrPC protein was present sporadically in the outer layers of smooth muscle and adventitia of larger blood vessels, when PrPC protein had disappeared from most of the smaller blood vessels (Fig. 3). PrPC was also found in the myometrium (not shown).

\section{Experiment 2}

Compared with NP animals, expression of $\operatorname{PrPC}$ mRNA in CAR tissue was unchanged across all days of early pregnancy (Fig. 4A). In FM, however, expression of PrPC mRNA increased $(P<0.05)$ from day 20 to day 28 of pregnancy and then decreased $(P<0.05)$ on day 30 to the levels present on day 24 (Fig. 4B).

PrPC protein was detected by western immunoblot analysis at a size estimated between 30 and $45 \mathrm{kDa}$ in both CAR tissue and FM in all stages of pregnancy that were evaluated (top of Fig. 5A and B). However, PrPC protein was expressed as a single band in CAR tissue and a doublet in FM. Compared with NP animals, expression of PrPC protein in CAR tissue was unchanged across all days of early pregnancy (Fig. 5A). Expression of PrPC protein in FM (Fig. 5B), however, increased $(P<0.05)$ from day 20 to day 28 of pregnancy and then decreased $(P<0.05)$ on day 30 . Therefore, in CAR tissue, neither
PrPC mRNA (Fig. 4A) nor PrPC protein (Fig. 5A) expression changed, whereas in FM the pattern of change for $\operatorname{PrPC}$ mRNA (Fig. 4B) and PrPC protein (Fig. 5B) expression closely paralleled each other. Thus, there was a significant $(P<0.01)$ tissue by day interaction for PrPC mRNA and PrPC protein expression.

In NP ICAR tissue, PrPC protein was present at the apical borders of the luminal epithelium and that of a few luminal glands (Fig. 6). PrPC protein was also present in the outer smooth muscle and adventitial layers of arterioles and venules and in scattered stromal cells of the deep ICAR tissue of the uterus (Fig. 6).

For CAR tissue, from day 20 to day 30 of pregnancy, PrPC was seen in the cytoplasm of flattened luminal epithelial cells apposed to the FM, whereas in FM, PrPC was localized to mononucleate, binucleate, and multinucleate trophoblast cells (Fig. 6).

In embryos, PrPC protein was predominantly present in the mesonephros on days 20-26 of pregnancy but was also found in the spinal cord and midbrain (Fig. 7). By day 26 of pregnancy, PrPC protein was also found in binucleate cells of the fetal liver. By days 28-30, PrPC protein was expressed in fetal mesonephros and in peripheral nerves in areas surrounding the spinal cord and the intestinal tract (Fig. 7).

\section{Discussion}

To our knowledge, this research presents the first data linking levels of expression of PrPC in the sheep uterus to stimulation by the uterotropic effects of $E_{2}$ and to placentation and uterine growth during early pregnancy in sheep. There are few reports of this phenomenon; however, many suggested functions for PrPC (Nicholas et al. 2009, Mehrpour \& Codogno 2010, Rigter et al. 2010) are similar to those known to be associated with $\mathrm{E}_{2}$-stimulated processes, such as cell proliferation and prevention of apoptosis (Johnson et al. 1997, Reynolds et al. 1998a,b). Additionally, our data extend our knowledge of which uteroplacental cells are expressing

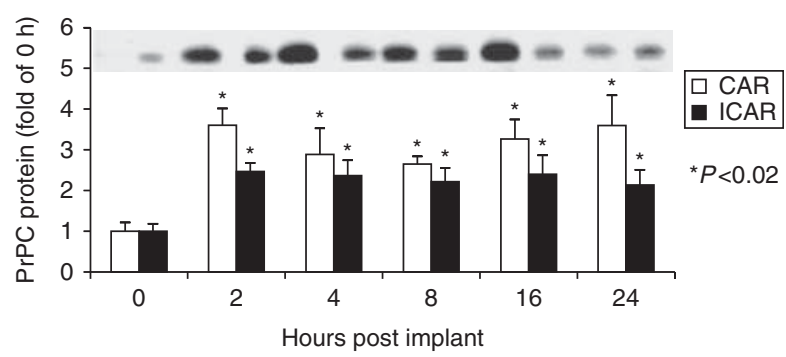

Figure 2 Expression of PrPC protein in CAR and ICAR tissues of $\mathrm{E}_{2}$-treated OVX ewes. Data were converted to fold increase over $0 \mathrm{~h}$ (controls), which were set at 1.0. PrPC was present in both CAR and ICAR tissues as a single protein band having a molecular weight between 30 and $45 \mathrm{kDa}$. A representative membrane of the western blots is shown on the top of the graph. The tissues and samples are shown in the same order as they are on the bar graph below. ${ }^{*} P<0.02$; means \pm s.E.M. are from western analysis. 

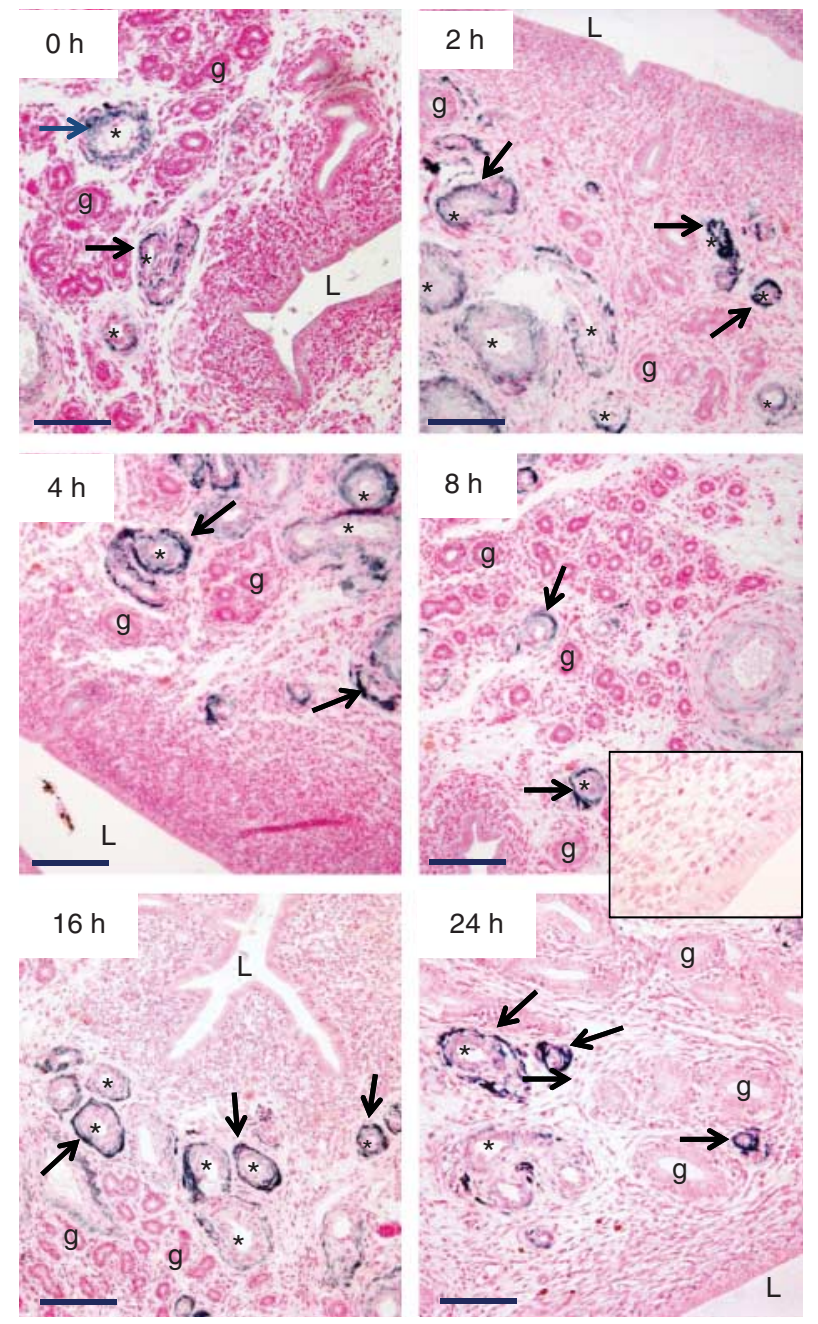

Figure 3 Representative image of immunolocalization of PrPC protein in endometrium of $\mathrm{E}_{2}$-treated OVX ewes. Arrows indicate PrPC-positive (dark) staining; counterstaining (pink) was with nuclear fast red. Note a lack of positive staining in control (inset), where primary antibody was replaced with mouse IgG. L, lumen of uterus; g, uterine gland; and *, blood vessel. Note that PrPC was expressed in arterioles and venules (primarily vascular smooth muscle and adventitia) at $0-24 \mathrm{~h}$ after $\mathrm{E}_{2}$ treatment, but PrPC was not present in glands or luminal epithelium. Size bar $=50 \mu \mathrm{m}$.

PrPC and how PrPC expression changes during the early stages of pregnancy, a time when some of the most dramatic developmental processes such as implantation and placentation are occurring under the influence of steroids and other factors (Zheng et al. 1996, Reynolds et al. 1998a,b, 2002, 2004, 2010, 2013, Johnson et al. 2006).

We found that $\mathrm{E}_{2}$ up-regulated $\operatorname{Pr} P C$ mRNA expression in CAR tissue, but not in ICAR tissue, by $8 \mathrm{~h}$ after $\mathrm{E}_{2}$ treatment, followed by a decrease at $24 \mathrm{~h}$. At $8 \mathrm{~h}$ following $E_{2}$ expression, we have shown that cell proliferation dramatically increases in association with maximal expression of mRNA for VEGFA (VEGF) and FGF2 (Reynolds et al. 1998a,b). In this study, within $2 \mathrm{~h}$ after $E_{2}$ treatment, PrPC protein expression increased by more than twofold in both the highly vascularized CAR tissue and in the glandular ICAR tissue, a reaction that was maintained through $24 \mathrm{~h}$ after $\mathrm{E}_{2}$. The significance of these changes is unclear because the function of PrPC in reproductive tissues is still unknown. Speculation that PrPC functions as a receptor for ligand uptake or transmembrane signaling is based on the fact that PrPC is found on cell surfaces and is recycled through endocytotic pathways, as are numerous other reproductive signaling molecules, including $\mathrm{LH}, \mathrm{FSH}$, TGF $\beta$, and IGF (Harris 1999, Forde et al. 2008, Rigter et al. 2010).

Although we cannot explain the discrepancy between mRNA and protein expression in this study, other investigators have reported dynamic regulation of prion protein turnover independent of gene expression or mRNA stability (Choi et al. 2010). Thus, differential regulation of uterine prion protein and mRNA levels seems to be a reasonable speculation and a worthwhile topic of future studies.

Our data demonstrate that $\mathrm{E}_{2}$ treatment not only influenced levels of PrPC protein expression in the NP uterus, but also affected the uterine cells that expressed
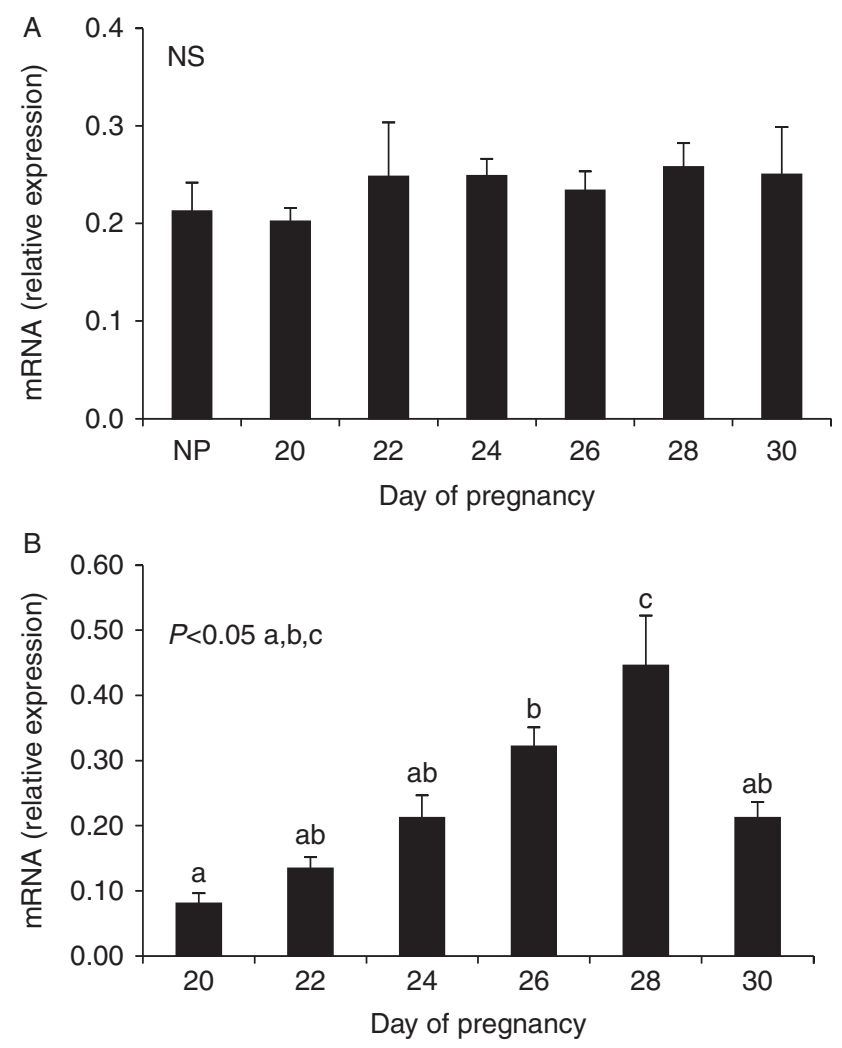

Figure 4 Expression of $\operatorname{Pr} P C \mathrm{mRNA}$ in (A) caruncle (CAR) tissue and (B) fetal membranes (FM) of ewes during early pregnancy. NS, not significant; ${ }^{a, b, c} P$ means \pm s.E.M. with different superscripts differ as indicated on the graph. Note that expression of $\operatorname{Pr} P C$ mRNA was unchanged in CAR tissue, but increased in FM from day 20 to day 28, and on day 30 returned to levels seen on days 22-26. 

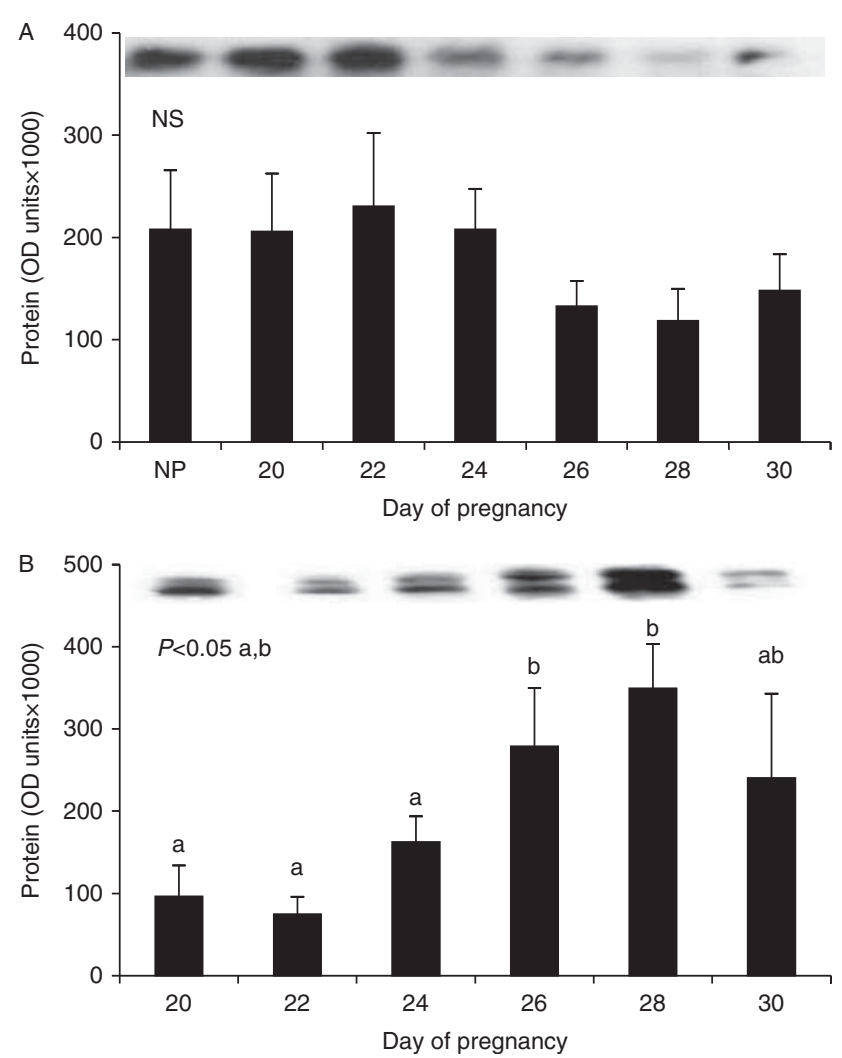

Figure 5 Expression of PrPC protein in caruncle (CAR) tissue (A) and fetal membranes (FM; B) during early pregnancy in ewes. A representative membrane of the western blots is shown on the top of the graph, where the tissues and samples are shown in the same order as they are on the bar graph below. PrPC protein had a molecular weight between 30 and $45 \mathrm{kDa}$. Note that PrPC protein was expressed a single band in CAR tissue, but as two protein bands in FM. NS, not significant; ${ }^{\mathrm{a}, \mathrm{b}} P$ means \pm s.E.M. with different superscripts differ as indicated on the graph. Values are from densitometry of the western blots. The pattern of change in FM for PrPC mRNA (Fig. 4) and PrPC protein expression closely paralleled each other.

PrPC protein. PrPC was mostly present in small and large blood vessels after $E_{2}$ treatment. This finding is interesting given the role of $E_{2}$ in promoting vascularization and increased blood flow to the uterus in preparation for uterine growth, implantation, and placentation (Magness et al. 1998, Reynolds et al. 1998a,b, 2002, 2004, 2010). PrPC was mainly present in the muscular and adventitial layers of the blood vessels. This may point to PrPC having a role in cell signaling cascades promoting the vascular development that is stimulated by $E_{2}$. Alternatively, it has been suggested that PrPC has a protective function that occurs after injury to blood vessels (Zocche Soprana et al. 2011).

Similar to others, we found that PrPC was present in the myometrium of NP and pregnant ewes but was unaffected by $\mathrm{E}_{2}$ treatment (Tanji et al. 1995, Tuo et al. 2001, Thumdee et al. 2007). The role of PrPC in regulation of myometrial function remains to be determined.
PrPC was found in apical areas of luminal epithelial cells and the epithelia of a few luminal glands in NP intact ewes used for controls in the early pregnancy study, but was not found in epithelial cells of the $E_{2}-$ treated OVX ewes. However, PrPC was found in the flattened epithelial cells of the maternal placenta during early pregnancy. These maternal epithelial cells are in close contact with the trophoblast cells of the fetal placenta, where PrPC was also present. PrPC has been found in the apical domain of human intestinal epithelial cells as well (De Keukeleire et al. 2007). Thus, we could speculate that epithelial cells and trophoblast cells might be the site where PrPC is converted to PrPSc in the placenta. In fact, PrPC has been shown to be overexpressed in multinucleate trophoblast cells, which are

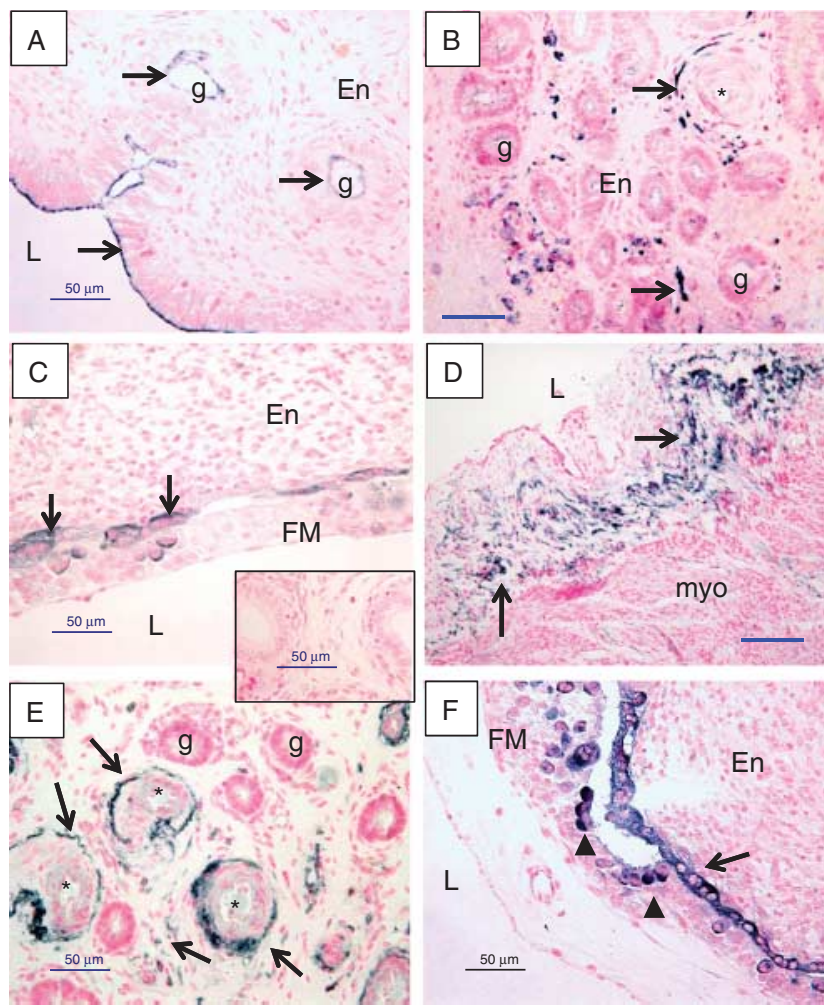

Figure 6 Representative images of PrPC protein localization (dark staining) in uterine and uteroplacental tissues of nonpregnant (NP; A and B) ewes and pregnant ewes from day 20 to day 30 after mating (C, D, E, and F). Note a lack of positive staining in control (inset in C), where primary antibody was replaced with mouse lgG. Arrows indicate some areas of PrPC-positive (dark) staining; the counterstaining (pink) was with nuclear fast red. L, lumen of uterus; $g$, uterine gland; En, endometrium; FM, fetal membranes (chorioallantois); myo, myometrium; and*, blood vessels. Note the presence of PrPC protein in NPanimals at the apical borders of the luminal epithelia and epithelia of luminal glands (A), larger blood vessels (primarily vascular smooth muscle and adventitia), and in some cells in stromal tissues of endometrium (B). In tissues from pregnancy, PrPC was in luminal epithelia adjacent to the FM (C), in myometrium (D), in luminal epithelial cells of the maternal caruncle (F; arrow), in bi- and multinucleated cells of the placenta (F; arrowheads), and in larger blood vessels and some cells in stromal tissues (E). Size bars $=50 \mu \mathrm{m}$. 

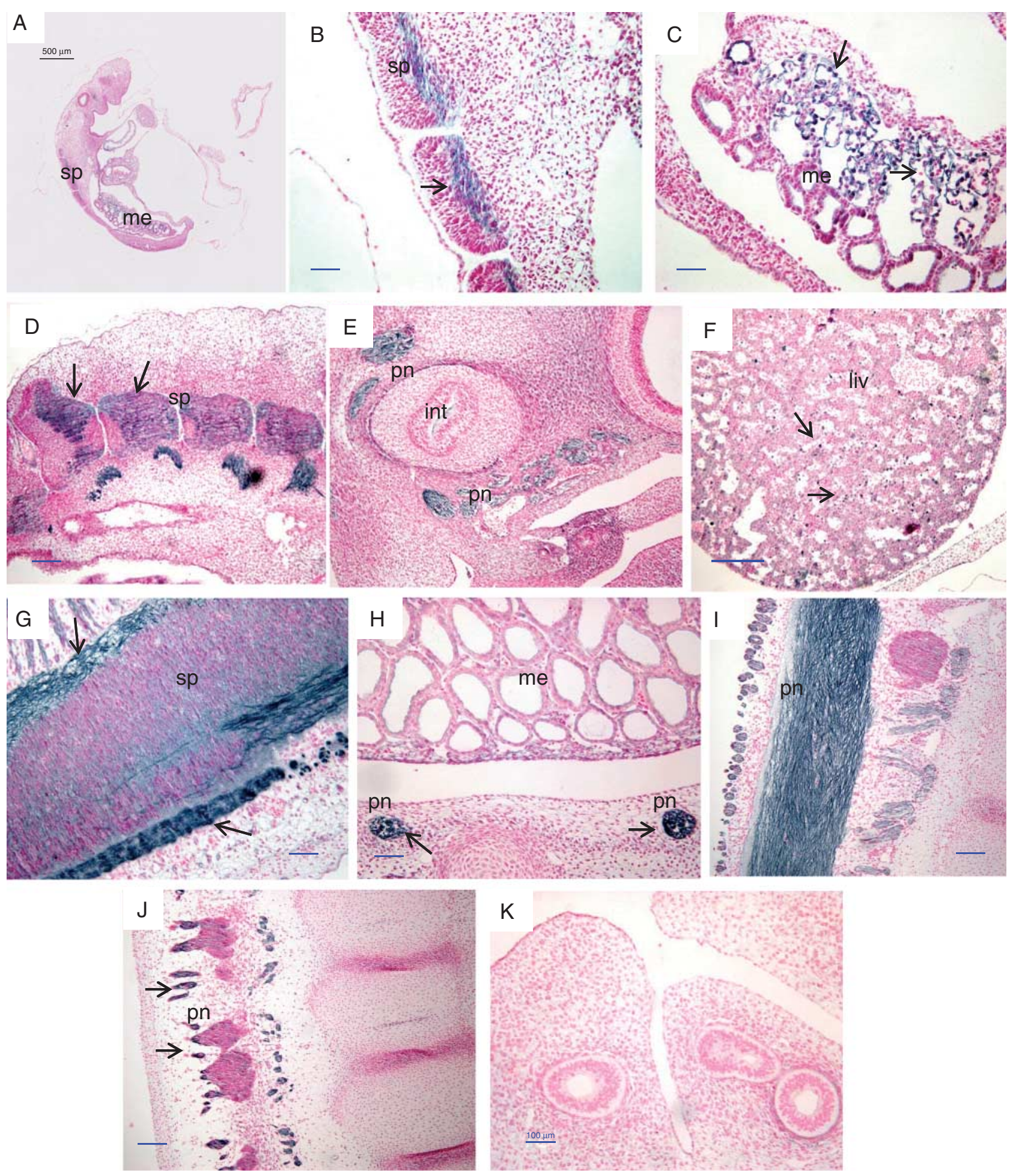

Figure 7 Representative images of immunolocalization of PrPC protein in a longitudinal section of an embryo on day 20 (A), and fetal tissues from days $20(B$ and C), $22(\mathrm{D}), 24(\mathrm{E}), 26(\mathrm{~F}), 28(\mathrm{G})$, and $30(\mathrm{H}, \mathrm{l}$, and J) of early pregnancy. Note a lack of positive staining in control (K) where primary antibody was replaced with mouse IgG. Arrows indicate areas of PrPC-positive (dark) staining in contrast to the background (pink) stained with nuclear fast red. sp, spinal cord; pn, peripheral nerves; liv, liver; int, intestine; and me, mesonephros. Note the presence of PrPC in the spinal cord $(B, D$, and $G)$, peripheral nerves associated with the intestine and other peripheral nerves $(E, H, I$, and $)$ ), liver $(F)$, and mesonephros $(C)$. Size bars $=500 \mu \mathrm{m}$ on A, $100 \mu \mathrm{m}$ on B-E and G-K, and $200 \mu \mathrm{m}$ on F. 
the sites where PrPSc accumulates and spreads to uninucleate trophoblast cells (Lacroux et al. 2007).

$\operatorname{PrPC}$ mRNA and PrPC protein expression have been shown to be greatest in the first trimester of human placenta growth (Donadio et al. 2007). In that study, expression of $\operatorname{PrPC} \mathrm{mRNA}$ and PrPC protein were unchanged in the maternal placenta during early pregnancy, but increased linearly until day 28 in the fetal placenta, similar to our observations in the present study. These data suggest a need for further studies of the function (s) of PrPC, especially during the rapid growth and differentiation of the fetal placenta and the developing embryo. For example, under the influence of $E_{2}$, the capillary volume of the placenta increases dramatically after day 18 of pregnancy and becomes increasingly more branched in the fetal placenta during later pregnancy resulting in smaller, more numerous capillaries, whereas in the maternal placenta capillary numbers remain about the same but their size increases to accommodate increased blood flow (Borowicz et al. 2007, Reynolds et al. 2010). Others have reported a role for PrPC in $\mathrm{Cu}$ homeostasis and regulation of hypoxic stress that may lead to IUGR (Alfaidy et al. 2013). In fact, during hypoxic conditions, PrPC expression is induced by HIF1 $\alpha$, which in turn is activated by $\mathrm{Cu}$ (Feng et al. 2009, Jeong et al. 2012). Thus, a role for placental PrPC in placental and fetal development seems likely.

It was noteworthy that PrPC protein presented as two bands in the western analysis of FM, but as only one in CAR tissue and the $E_{2}$-treated OVX ewe endometrium. These differences likely reflect the pattern of PrPC glycosylation and also could be related to the length of the PrPC transcript after its activation by proteolytic cleavage. PrPC can exist in three variable forms, as un-, mono-, and di-glycosylated at either of two asparagine residues in its mature length of 208 residues (Cancellotti et al. 2013). Thus, the size of PrPC protein in western blots has been reported as varying from 23 to $44 \mathrm{kDa}$ in sheep reproductive tissues (Horiuchi et al. 1995, Tuo et al. 2001). However, recent reports have suggested that there is a well-conserved hydrophobic core containing a site, commonly referred to as the $\alpha$-cleavage site, where PrPC is cleaved during normal proteolysis into two fragments, C1 (C-terminal) and N1 (N-terminal) (Yusa et al. 2012). These $C 1$ and $N 1$ fragments were detected in western blots after removal of glycosylation sites (Yusa et al. 2012, Cancellotti et al. 2013). When proteolysis of PrPC is blocked, it apparently becomes neurotoxic, suggesting that the normal physiological function of PrPC depends on its cleavage into $\mathrm{C} 1$ and $\mathrm{N} 1$ (Yusa et al. 2012). Therefore, the two bands for PrPC present in the FM may suggest that PrPC has a specific function in the fetal placenta but not in the maternal placenta. The increase in PrPC expression in the fetal placenta from day 20 to day 28 of pregnancy that we report herein also supports this suggestion, because it corresponds with rapid growth and vascularization of the placenta (Reynolds \& Redmer 1992, Grazul-Bilska et al. 2010, 2011).
Expression of PrPC mRNA and PrPC protein in bovine and ovine fetuses and maternal tissues have been evaluated previously, and the recently reported timeand tissue-specific expression closely resemble the results of our study (Thumdee et al. 2007, Peralta et al. 2012). Early sheep pregnancy (gestation $=\sim 145$ days) from day 20 to day 30 closely correlates with the intervals reported for bovine early pregnancy (gestation $=\sim 278$ days) from day 27 to day 39 (Peralta et al. 2012). In this study, PrPC was predominantly present in ovine neural tissues of the embryo in early pregnancy, but was also present in liver and mesonephros, as early as day 20 of pregnancy and was expressed in the same cell-specific manner as in cows. On day 26, PrPC expression in the liver was found in scattered multinucleated cells, and these likely were macrophages, similar to the findings in cows (Peralta et al. 2012). The expression of PrPC in neural tissues of the developing embryo suggests that PrPC has a role in neural differentiation (Peralta et al. 2011, 2012). We found PrPC in the spinal cord of day 20 sheep embryos and PrPC expression in peripheral nerves by days 26-30, which was also similar to PrPC expression in cows (Peralta et al. 2012).

As our research has demonstrated that $E_{2}$ increased PrPC expression in the uterus, research to evaluate $E_{2}$ effects on PrPC expression in the brain should be encouraged. In fact, $E_{2}$ has recently been found to prevent PrPSc infection of healthy cells and to enable PrPC maintenance as a treatment for TSE infection (Molloy \& McMahon 2014). Interesting comparisons are also being made between onset of $A D$ and actions of PrPC in the brain. The research demonstrates that PrPC may be a receptor for soluble amyloid $B(A B)$ peptide fragments or may serve as an inhibitor of the neurotoxic effects of insoluble AB fragments (Laurén et al. 2009, Nieznanski et al. 2012). Additionally, $\mathrm{E}_{2}$ has been shown to have neuroprotective effects in postmenopausal women including delay of the onset of AD (Tang et al. 1996, Dubal \& Wise 2002, Wise et al. 2009, Barron \& Pike 2012). Thus, if PrPC is an important factor in neuroprotection against $A D$, future studies should continue evaluating how $E_{2}$ affects prion expression in the brain and possibly blocks AD.

In summary, we have presented novel data linking $E_{2}$ with increases in expression of PrPC in the uterus and have shown that PrPC expression increases in a timespecific manner in the fetal placenta during early pregnancy. Moreover, we have demonstrated localization of $\operatorname{PrPC}$ to blood vessels after $E_{2}$ treatment, suggesting a role for PrPC in the uterotropic effects of $E_{2}$, including regulation of vascular function and growth. Additionally, we have reported the cell-specific expression of PrPC in epithelia of the uterine endometrium and in trophoblast cells of the FM and suggest that PrPC may be involved in the adhesion of FM to the endometrium in sheep. These sites of robust PrPC 
expression in the uterus and placenta are likely those where conversion to PrPSc occurs and that may provide clues as to how scrapie is spread in sheep during lambing. The novel evidence that $E_{2}$ increases PrPC expression in uterine tissues may lead to future studies focused on whether $E_{2}$ increases PrPC expression in the other tissues, and especially brain and nervous system where PrPC may be a key factor in combating AD.

\section{Declaration of interest}

The authors declare that there is no conflict of interest that could be perceived as prejudicing the impartiality of the research reported.

\section{Funding}

This project was supported by funding from the Animal Disease Research Unit, Animal Research Service, U.S. Department of Agriculture (5348-32000-021-00D), USDA grant (2007-01215) to L P Reynolds and A T Grazul-Bilska, Hatch Project ND1727, and the INBRE program of the National Center for Research Resources, NIH (grant number P20RR016741).

\section{Acknowledgements}

The authors acknowledge Dr Katherine I O'Rourke, USDAARS, Pullman, WA, for funding and leadership in the PrPC studies at North Dakota State University. They also acknowledge Dr Jerzy Bilski, Dr Pawel Borowicz, Ms Tammi Neville, Mr James D Kirsch, Mr Kim C Kraft, Mr Robert Weigl, Mr Terry Skunberg, and other members of our laboratories and department for their assistance and the efforts of several of our graduate and undergraduate students in this research project: Roza Yunosova, Mahalakshmi Razdan, Anirudh Gautam, and Mathilde Rupin.

\section{References}

Alfaidy N, Chauvet S, Donadio-Andrei S, Salomon A, Saoudi Y, Richaud P, Aude-Garcia C, Hoffmann P, Andrieux A, Moulis JM et al. 2013 Prion protein expression and functional importance in developmental angiogenesis: role in oxidative stress and copper homeostasis. Antioxidants \& Redox Signaling 18 400-411. (doi:10.1089/ars.2012.4637)

Barron AM \& Pike CJ 2012 Sex hormones, aging, and Alzheimer's disease. Frontiers in Bioscience 4 976-997. Review. (doi:10.2741/E434)

Borowicz PP, Arnold DR, Johnson ML, Grazul-Bilska AT, Redmer DA \& Reynolds LP 2007 Placental growth throughout the last two-thirds of pregnancy in sheep: vascular development and angiogenic factor expression. Biology of Reproduction 76 259-267. (doi:10.1095/biolreprod.106.054684)

Brandner S, Isenmann S, Raeber A, Fischer M, Sailer A, Kobayashi Y, Marino S, Weissmann C \& Aguzzi A 1996 Normal host prion protein necessary for scrapie-induced neurotoxicity. Nature 379 339-343. (doi:10.1038/379339a0)

Cancellotti E, Mahal SP, Somerville R, Diack A, Brown D, Piccardo P, Weissmann C \& Manson JC 2013 Post-translational changes to PrP alter transmissible spongiform encephalopathy strain properties. $E M B O$ Journal 32 756-769. (doi:10.1038/emboj.2013.6)

Choi CJ, Anantharam V, Martin DP, Nicholson EM, Richt JA, Kanthasamy A \& Kanthasamy AG 2010 Manganese upregulates cellular prion protein and contributes to altered stabilization and proteolysis: relevance to role of metals in pathogenesis of prion disease. Toxicological Sciences $\mathbf{1 1 5}$ 535-546. (doi:10.1093/toxsci/kfq049)

Colby DW \& Prusiner SB 2011 De novo generation of prion strains. Nature Reviews. Microbiology 11 771-777. (doi:10.1038/nrmicro2650)

De Keukeleire B, Donadio S, Micoud J, Lechardeur D \& Benharouga M 2007 Human cellular prion protein hPrPC is sorted to the apical membrane of epithelial cells. Biochemical and Biophysical Research Communications 354 949-954. (doi:10.1016/j.bbrc.2007.01.096)

Donadio S, Alfaidy N, De Keukeleire B, Micoud J, Feige JJ, Challis JR \& Benharouga M 2007 Expression and localization of cellular prion and COMMD1 proteins in human placenta throughout pregnancy. Placenta 28 907-911. (doi:10.1016/j.placenta.2006.11.006)

Dubal DB \& Wise PM 2002 Estrogen and neuroprotection: from clinical observations to molecular mechanisms. Dialogues in Clinical Neuroscience 4 149-161.

Evoniuk JM, Berg PT, Johnson ML, Larson DM, Maddock TD, Stoltenow CL, Schauer CS, O'Rourke KI \& Redmer DA 2007 Associations between genotypes at codon 171 and 136 of the prion protein gene and production traits in market lambs. American Journal of Veterinary Research 68 1073-1078. (doi:10.2460/ajvr.68.10.1073)

Feng W, Ye F, Xue W, Zhou Z \& Kang YJ 2009 Copper regulation of hypoxiainducible factor-1 activity. Molecular Pharmacology 75 174-182. (doi:10.1124/mol.108.051516)

Forde N, Rogers M, Canty MJ, Lonergan P, Smith GW, Coussens PM, Ireland JJ \& Evans AC 2008 Association of the prion protein and its expression with ovarian follicle development in cattle. Molecular Reproduction and Development 75 243-249. (doi:10.1002/mrd.20807)

Grazul-Bilska AT, Borowicz PP, Johnson ML, Minten MA, Bilski JJ, Wroblewski R, Redmer DA \& Reynolds LP 2010 Placental development during early pregnancy in sheep: vascular growth and expression of angiogenic factors in maternal placenta. Reproduction 140 165-174. (doi:10.1530/REP-09-0548)

Grazul-Bilska AT, Johnson ML, Borowicz PP, Minten M, Bilski JJ, Wroblewski R, Velimirovich M, Coupe LR, Redmer DA \& Reynolds LP 2011 Placental development during early pregnancy in sheep: cell proliferation, global methylation, and angiogenesis in the fetal placenta. Reproduction 141 529-540. (doi:10.1530/REP-10-0505)

Halliday S, Houston F \& Hunter N 2005 Expression of PrPC on cellular components of sheep blood. Journal of General Virology 86 1571-1579. (doi:10.1099/vir.0.80561-0)

Harris DA 1999 Cellular biology of prion diseases. Clinical Microbiology Reviews 12 429-444.

Horiuchi M, Yamazaki N, Ikeda T, Ishiguro N \& Shinagawa M 1995 A cellular form of prion protein (PrPC) exists in many non-neuronal tissues of sheep. Journal of General Virology 76 2583-2587. (doi:10.1099/ 0022-1317-76-10-2583)

Jeong JK, Seo JS, Moon MH, Lee YJ, Seol JW \& Park SY 2012 Hypoxia-inducible factor- $1 \propto$ regulates prion protein expression to protect against neuron cell damage. Neurobiology of Aging 33 1006-1026. (doi:10.1016/j.neurobiolaging.2011.09.037)

Johnson ML, Redmer DA \& Reynolds LP 1997 Effects of ovarian steroids on uterine growth, morphology, and cell proliferation in ovariectomized, steroid-treated ewes. Biology of Reproduction 57 588-596. (doi:10. 1095/biolreprod57.3.588)

Johnson ML, Grazul-Bilska AT, Redmer DA \& Reynolds LP 2006 Effects of estradiol- $17 \beta$ on expression of mRNA for seven angiogenic factors and their receptors in the endometrium of ovariectomized (OVX) ewes. Endocrine 30 333-342. (doi:10.1007/s12020-006-0012-5)

Kirk RE 1982 Experimental Design: Procedures for the Behavioral Sciences, 2nd edn Belmont, CA: Brooks/Cole.

Lacroux C, Corbière F, Tabouret G, Lugan S, Costes P, Mathey J, Delmas JM, Weisbecker JL, Foucras G, Cassard H et al. 2007 Dynamics and genetics of PrPSc placental accumulation in sheep. Journal of General Virology 88 1056-1061. (doi:10.1099/vir.0.82218-0)

Laurén J, Gimbel DA, Nygaard HB, Gilbert JW \& Strittmatter SM 2009 Cellular prion protein mediates impairment of synaptic plasticity by amyloid- $\beta$ oligomers. Nature 457 1128-1132. (doi:10.1038/nature 07761)

Magness RR, Phernetton TM \& Zheng J 1998 Systemic and uterine blood flow distribution during prolonged infusion of $17 \beta$-estradiol. American Journal of Physiology $275 \mathrm{H} 731-\mathrm{H} 743$. 
Mehrpour M \& Codogno P 2010 Prion protein: from physiology to cancer biology. Cancer Letters 290 1-23. (doi:10.1016/j.canlet.2009.07.009)

Molloy B \& McMahon HE 2014 A cell-biased effect of estrogen in prion infection. Journal of Virology 88 1342-1353. (doi:10.1128/JVI.02936-13)

Nicholas O, Gavin R \& del Rio JA 2009 New insights into cellular prion protein (PrPC) functions: the "ying and yang" of a relevant protein. Brain Research Reviews 61 170-184. (doi:10.1016/j.brainresrev.2009.06.002)

Nieznanski K, Choi JK, Chen S, Surewicz K \& Surewicz WK 2012 Soluble prion protein inhibits amyloid-ß (Aß) fibrillization and toxicity. Journal of Biological Chemistry 287 33104-33108.

Peralta OA, Huckle WR \& Eyestone WH 2011 Expression and knockdown of cellular prion protein (PrPC) in differentiating mouse embryonic stem cells. Differentiation 81 68-77. (doi:10.1016/j.diff.2010.09.181)

Peralta OA, Huckle WR \& Eyestone WH 2012 Developmental expression of the cellular prion protein $(\operatorname{Pr}(\mathrm{C})$ in bovine embryos. Molecular Reproduction and Development 79 488-498. (doi:10.1002/mrd.22057)

Reynolds LP \& Redmer DA 1992 Growth and microvascular development of the uterus during early pregnancy in ewes. Biology of Reproduction 47 698-708. (doi:10.1095/biolreprod47.5.698)

Reynolds LP \& Redmer DA 1995 Uteroplacental vascular development and placental function. Journal of Animal Science 73 1839-1851.

Reynolds LP \& Redmer DA 2001 Angiogenesis in the placenta. Biology of Reproduction 64 1033-1040. Review. (doi:10.1095/biolreprod64.4. 1033)

Reynolds LP, Kirsch JD, Kraft KC, Knutson DL, McClaflin WJ \& Redmer DA 1998a Time-course of the uterine response to estradiol-17 $\beta$ in ovariectomized ewes: uterine growth and microvascular development. Biology of Reproduction 59 606-612. (doi:10.1095/biolreprod59.3.606)

Reynolds LP, Kirsch JD, Kraft KC \& Redmer DA $1998 b$ Time-course of the uterine response to estradiol-17 $\beta$ in ovariectomized ewes: expression of angiogenic factors. Biology of Reproduction 59 613-620. (doi:10.1095/ biolreprod59.3.613)

Reynolds LP, Grazul-Bilska AT \& Redmer DA 2002 Angiogenesis in the female reproductive organs: pathological implications. International Journal of Experimental Pathology 83 151-163. Review. (doi:10.1046/j. 1365-2613.2002.00277.x)

Reynolds LP, Borowicz PP, Vonnahme KA, Johnson ML, Grazul-Bilska AT, Wallace JM, Caton JS \& Redmer DA 2004 Animal models of placental angiogenesis. Placenta 26 689-708. (doi:10.1016/j.placenta.2004.11.010)

Reynolds LP, Borowicz PP, Caton JS, Vonnahme KA, Luther JS, Buchanan DS, Hafez SA, Grazul-Bilska AT \& Redmer DA 2010 Uteroplacental vascular development and placental function: an update. International Journal of Developmental Biology 54 355-366. (doi:10.1387/ijdb.082799/r)

Reynolds LP, Vonnahme KA, Lemley CO, Redmer DA, Grazul-Bilska AT, Borowicz PP \& Caton JS 2013 Maternal stress and placental vascular function and remodeling. Current Vascular Pharmacology 11 564-593. (doi:10.2174/1570161111311050003)
Rigter A, Langeveld JP, van Zijderveld FG \& Bossers A 2010 Prion protein self-interactions: a gateway to novel therapeutic strategies? Vaccine $\mathbf{2 8}$ 7810-7823. (doi:10.1016/j.vaccine.2010.09.012)

SAS Institute 2008 SAS:User's Guide, Statistics, 5th edn. Cary, NC: Statistical Analysis System Institute.

Tang MX, Jacobs D, Stern Y, Marder K, Schofield P, Gurland B, Andrews H \& Mayeux R 1996 Effect of oestrogen during menopause on risk and age at onset of Alzheimer's disease. Lancet 348 429-432. (doi:10.1016/ S0140-6736(96)03356-9)

Tanji K, Saeki K, Matsumoto Y, Takeda M, Hirasawa K, Doi K, Matsumoto Y \& Onodera T 1995 Analysis of PrPc mRNA by in situ hybridization in brain, placenta, uterus and testis of rats. Intervirology 38 309-315.

Thumdee P, Ponsuksili S, Murani E, Nganvongpanit K, Gehrig B, Tesfaye D, Gilles M, Hoelker M, Jennen D, Griese J et al. 2007 Expression of the prion protein gene (PRNP) and cellular prion protein $(\mathrm{PrPc})$ in cattle and sheep fetuses and maternal tissues during pregnancy. Gene Expression Patterns 13 283-297. (doi:10.3727/000000006780 666984)

Tuo W, Zhuang D, Knowles DP, Cheevers WP, Sy MS \& O'Rourke KI 2001 Prp-c and Prp-Sc at the fetal-maternal interface. Journal of Biological Chemistry 276 18229-18234. (doi:10.1074/jbc.M00888 7200)

Wenrich BR \& Trumbo TA 2012 Interaction of nucleic acids with Coomassie Blue G-250 in the Bradford assay. Analytical Biochemistry 428 93-95. (doi:10.1016/j.ab.2012.06.014)

Wise PM, Suzuki S \& Brown CM 2009 Estradiol: a hormone with diverse and contradictory neuroprotective actions. Dialogues in Clinical Neuroscience 11 297-303.

Yusa S, Oliveira-Martins JB, Sugita-Konishi Y \& Kikuchi Y 2012 Cellular prion protein: from physiology to pathology. Viruses 4 3109-3131. (doi:10.3390/v4113109)

Zheng J, Johnson ML, Redmer DA \& Reynolds LP 1996 Estrogen and progesterone receptors, cell proliferation, and c-fos expression in the ovine uterus during early pregnancy. Endocrinology 137 340-348. (doi:10.1210/endo.137.1.8536633)

Zocche Soprana H, Canes Souza L, Debbas V \& Martins Laurindo FR 2011 Cellular prion protein $(\operatorname{PrP}(\mathrm{C}))$ and superoxide dismutase (SOD) in vascular cells under oxidative stress. Experimental and Toxicologic Pathology 63 229-236. (doi:10.1016/j.etp.2009.12.004)

Received 29 October 2013

First decision 17 December 2013

Revised manuscript received 4 March 2014

Accepted 24 March 2014 